\title{
ПРОБЛЕМНІ ПИТАННЯ ЗАПОБІГАННЯ НЕЗАКОННОМУ ПОВОДЖЕННЮ З РАДІОАКТИВНИМИ МАТЕРІАЛАМИ В УКРАЇНІ
}

\author{
Доліщук М. Т., Плужнік О. І.
}

Статтю присвячено аналізу проблемних питань щодо запобігання суспільно небезпечних дій (бездіяльності), які пов'язані з обігом ядерних матеріалів і радіоактивних речовин. Результати теоретичного дослідження дали змогу встановити, що шкода або збитки, що можуть бути завдані людині і навколишньому середовищу в результаті скоєння злочинів, пов'язаних з обігом ядерних матеріалів і радіоактивних речовин, $\epsilon$ істотними $і$ часто незворотними, радіоактивна безпека $\epsilon$ загальносвітовою та універсальною проблемою сучасного суспільства.

Ключові слова: ядерні матеріали, радіоактивні речовини, безпека навколишнього середовища, атомна енергія, злочини, пов'язані з обігом ядерних матеріалів і радіоактивних речовин.

Статья посвящена анализу проблемных вопросов по предотвращению общественно опасных действий (бездействия), связанных с оборотом ядерных материалов и радиоактивных веществ. Результаты теоретического исследования позволили установить, что вред или ущерб, которые могут быть причинены человеку и окружающей среде в результате совершения преступлений, связанных с оборотом ядерных материалов и радиоактивных веществ, являются существенными и часто необратимыми, радиоактивная безопасность является общемировой и универсальной проблемой современного общества.

Ключевые слова: ядерные материалы, радиоактивные вещества, безопасность окружающей среды, атомная энергия, преступления, связанные с оборотом ядерных материалов и радиоактивных веществ.

The article is devoted to the analysis of problem issues concerning the prevention of socially dangerous actions (inaction), which are related to the circulation of nuclear materials and radioactive substances. An important part of the problem is society's attitude to the danger of radioactive contamination. In recent decades, society has been particularly concerned about the use of ionizing radiation in energy, industry, and medicine. The illiterate handling of ionizing radiation is a crime, and the ignorance of the foundations of radiation safety, its principles and means are generating radio phobia.

An authors mark that the harm or damage that may be inflicted on humans and the environment as a result of the commission of crimes related to the circulation of nuclear materials and radioactive substances are substantial and often irreversible. Over the years of independence in Ukraine, more than ten attempts have been recorded for the export of radioactive materials abroad, and up to 20 cases of illicit radioactive material handling annually. The prerequisite for ensuring environmental and radiation safety is the use of state mechanisms and measures of economic, administrative and regulatory nature. There is insufficient research in the area of illicit trafficking in nuclear materials and radioactive substances that can significantly improve the situation and positively affect further environmental changes.

The analysis of problem issues concerning the prevention of socially dangerous actions (inactivity) that are related to the circulation of nuclear materials and radioactive substances emphasizes the need to prevent the illicit management of radioactive substances and nuclear materials, which will save the environment not only of our country, but also of the Earth. The results of the theoretical study allowed establishing that radioactive safety is a global and universal problem of modern society.

Key words: nuclear materials, radioactive substances, environmental safety, atomic energy, crimes related to the circulation of nuclear materials and radioactive substances.

Постановка проблеми та її актуальність. Як суверенна і незалежна, демократична, соціальна і правова держава, якою відповідно до норм Основного Закону оголосила себе Україна, наша держава мусить дотримуватися вимог міжнародного співробітництва щодо забезпечення радіоактивної безпеки. Останніми десятиліттями в суспільстві викликає особливе занепокоєння застосування іонізуючого випромінювання в енергетиці, промисловості, в медицині. Неграмотне поводження з іонізуючим випромінюванням - злочин, а незнання основ радіаційної безпеки, принципів і засобів іiі забезпечення породжує радіофобію. Неблагополучна радіаційна обстановка має основні причини для такого становища, а саме несправності в роботі атомних об'єктів, велика кількість накопичених радіоактивних відходів, відсутність необхідної кількості технічних засобів для забезпечення безпечного поводження з цими відходами та відпрацьованим ядерним паливом, відсутність надійних сховищ для їх тривалого зберігання і (або) захоронення. Всі ці причини $є$ передумовами для фактів незаконного поводження з ядерними матеріалами та радіоактивними речовинами, включаючи випадки розкрадання зазначених речовин і матеріалів. Останніми десятиліттями XX століття і нині одним 3 найбільш латентних видів злочинів $\epsilon$ передбачені кримінальним законом суспільно небезпечні дії (бездіяльність), пов'язані з обігом ядерних матеріалів і радіоактивних речовин. Кримінальний кодекс України містить низку статей, в яких радіоактивні речовини вказані предметом скоєння злочину. Маються на увазі злочини, передбачені ст. ст. 265, 265-1, 266, 267 КК України.

Аналіз останніх досліджень і публікацій. В Україні радіоактивні матеріали (ядерні та радіоактивні речовини, радіоактивні відходи та джерела іонізуючого випромінювання) застосовуються в ядерно-енергетичному комплексі, зберігаються в шести сховищах державних міжобласних спеціалізованих комбінатів «Радон», п'яти сховищах військово-промислового комплексу, розташовані в 30-кілометровій зоні відчуження Чорнобильської АЕС, у пунктах захоронення відходів дезактивації, $\epsilon$ в медичних установах, на промислових підприємствах та в науково-дослідних лабораторіях.

Доліщук М. Т., Плужнік О. І., 2019 
В уранодобувній i переробній промисловості ядерноенергетичного комплексу України накопичено близько 65 млн тонн твердих низькоактивних відходів [1].

За роки незалежності в Україні зафіксовано більше десяти спроб вивезення за кордон радіоактивних матеріалів і щорічно до 20 випадків незаконного поводження з радіоактивними матеріалами.

Кількість злочинів, зареєстрованих органами МBC України, згідно з Кримінальним кодексом України за різними його статтями, становить:

75\% - порушення правил поводження з вибуховими, легкозаймистими речовинами, а також радіаційними матеріалами (ст. 267 КК);

$20 \%$ - порушення правил ядерної та радіаційної безпеки (ст. 274 КК);

5\% - загроза крадіжки та використання радіоактивних матеріалів (ст. 266 КК) [2, с. 5].

До кримінально-правових питань аналізу та кваліфікації злочинів, пов'язаних з обігом ядерних матеріалів і радіоактивних речовин, зверталися деякі вчені. Цим проблемам були присвячені роботи В.П. Тихого, В.Д. Іванова, О.Л. Дубовик і деяких інших авторів. Досліджень, безпосередньо присвячених кримінально-правовому аналізу незаконного обігу ядерних матеріалів і радіоактивних речовин, системному їх вивченню, не вистачає.

Метою цієї статті $\epsilon$ спроба проаналізувати проблемні питання запобігання суспільно небезпечних дій (бездіяльності), які пов'язані з обігом ядерних матеріалів і радіоактивних речовин.

Виклад основного матеріалу. Шкода або збитки, що можуть бути завдані людині і навколишньому середовищу в результаті скоєння злочинів, пов'язаних з обігом ядерних матеріалів і радіоактивних речовин, $\epsilon$ істотними і часто незворотними. Це пов'язано перш за все з тим, що всі речовини, які $\epsilon$ предметом досліджуваних нами злочинів, мають властивість радіоактивності.

Серед загального складу потенційних загроз виділяють загрози ядерних матеріалів, радіоактивних речовин і виробів, що містять ці матеріали і речовини. До них, зокрема, належать: розкрадання ядерних матеріалів з метою подальшого створення ядерної або радіологічної зброї; вчинення радіологічних диверсій; розкрадання з метою подальшого продажу. Інший аспект проблеми пов'язаний із запобіганням можливих інцидентів, пов'язаних з незаконним обігом і навіть розкраданням радіоактивних речовин, а також можливим захопленням атомних електростанцій та інших атомних об'єктів з боку терористичних організацій.

Важливою частиною проблеми $\epsilon$ ставлення суспільства до небезпеки радіоактивного забруднення. Згідно 3 критеріями, розробленими в США 3 метою оцінки ставлення населення до різних соціальних екологічних проблем, проблема радіації стоїть на 26-му місці, тоді як забруднення важкими металами та хімічними речовинами - на першому і другому.

Для злочинів, пов'язаних з обігом ядерних матеріалів і радіоактивних речовин, суспільна небезпека $\epsilon$ необхідною ознакою злочину i, звичайно, однією з головних відмінних ознак серед інших видів злочинів за видами і тяжкістю завданої ними шкоди.

Безпека забезпечується за допомогою захисту об'єктів системи забезпечення безпеки особливо небезпечних об'єктів від потенційних загроз. До комплексної системи мають входити: система фізичного захисту, системи обліку і контролю ядерних матеріалів, радіоактивних речовин і відходів; система заходів ядерної та радіаційної безпеки; система протипожежного захисту; інші системи, що забезпечують реалізацію заходів безпечного функціонування ядерних об'єктів. Необхідною умовою забезпечення екологічної та радіаційної безпеки $\epsilon$ використання державою механізмів і заходів економічного, адміністративного і нормативно-правового характеру.

Наявна практика показала, що розкрадання ядерних матеріалів відбувалися, як правило, працівниками об'єктів, на яких виготовляються, зберігаються або використовуються радіоактивні речовини, і здебільшого шляхом вільного доступу (з місць складування відходів, напівфабрикатів). До реалізації викраденого залучалися різні особи (посередники і продавці), до числа яких входили в основному родичі, товариші по роботі, знайомі, що працюють на тих же підприємствах або в різних комерційних структурах, або тимчасово не працюють. Однією з цілей їхніх дій була нажива. Коло осіб, що беруть участь у процесі протиправних оборудок, складалося стихійно через пошук каналів збуту, тому говорити про існування мафіозних організованих угруповань, що спеціалізуються на крадіжці радіоактивних матеріалів, не можна. Предметом розкрадань в основному були джерела іонізуючого випромінювання, що використовуються в незначних кількостях у різних виробничо-технічних приладах, окремих датчиках протипожежної безпеки, обладнанні й установках.

Предметами правопорушень, пов'язаних 3 незаконним поводженням з радіоактивними матеріалами, $\epsilon$ ядерні матеріали, радіоактивні речовини і радіоактивні відходи, а також радіаційні джерела і джерела радіоактивного (іонізуючого) випромінювання.

Ядерні матеріали - це матеріали, що містять або здатні відтворити ядерні речовини, які діляться (розщеплюються), в тому числі: а) збіднений уран; б) опромінений ядерний матеріал; в) збагачений уран; г) відпрацьоване ядерне паливо; ґ) природний уран; д) радіоактивні відходи; е) слабо опромінений ядерний матеріал; $\epsilon$ ) вироби на їх основі.

Радіоактивні речовини - це не пов'язані з ядерними матеріалами речовини в будь-якому агрегатному стані, що випускають іонізуюче випромінювання. До них належать: радіоактивні речовини, що випромінюють альфаабо бета-частинки (стронцій-90, фосфор-32, сірка-35, вуглець-14 і ін.); радіоактивні речовини, що випромінюють альфа-, бета-частинки і гамма-кванти (радій226, кобальт-60, йод-131, іридій-192, цезій-137 і ін.); радіоізотопні джерела нейтронів або змішаного гамма-випромінювання.

Радіоактивні відходи - це ядерні матеріали та радіоактивні речовини, подальше використання яких не передбачається. Поняття радіоактивних відходів включає не тільки речовини і матеріали, що не підлягають подальшому використанню, а й ті вироби, прилади, обладнання, ґрунт, породи, об'єкти біологічного походження, в яких вміст радіонуклідів перевищує рівні, встановлені нормативними актами.

Радіаційні джерела - це не пов'язані з ядерними установками, комплексами, установками, апаратами, обладнанням і виробами, в яких містяться радіоактивні речовини або генерується іонізуюче випромінювання. 
Джерело іонізуючого випромінювання - це радіоактивна речовина або пристрій, що випускає або здатне випускати іонізуюче випромінювання. Іонізуюче випромінювання - це потік заряджених або нейтральних частинок і квантів електромагнітного випромінювання, проходження яких через речовину призводить до іонізації і збудження атомів (альфа-, бета- і гамма- розпад).

Проблему незаконного поводження 3 ядерними та радіоактивними матеріалами помилково було б пов'язувати тільки з однією будь-якою державою, зокрема з Україною. Ця проблема $є$ універсальною.

Історія розвитку використання атомної енергії та їі компонентів як у військових, так і в мирних цілях свідчить, що на перших етапах під час реалізації національних атомних програм держави ставили перед собою перш за все науково-дослідні, військово-стратегічні, техніко-економічні та політичні цілі. Екологічні питання або взагалі не вирішувалися, або їх рішення відкладалося на майбутнє. Також не приділялося належної уваги вирішенню правових проблем використання атомної енергії i, зокрема, безпечного поводження з радіоактивними речовинами та відходами. Однак аварії у виробничому об'єднанні «Маяк» у 1957 р., у Віндскейлі (Великобританія, 1957 р.), на АEC у ТриМайл-Айленд (США, 1979 р.) і особливо аварія на АЕС у Чорнобилі в 1986 р. поставили проблему правового захисту навколишнього середовища від радіоактивного забруднення та безпеку поводження з радіоактивними речовинами на перше місце у вирішенні проблем використання атомної енергії. Натепер проблема поводження з радіоактивними речовинами $\epsilon$ однією з головних проблем ядерної енергетики і промисловості.

Конвенція про фізичний захист ядерного матеріалу від 3 березня 1980 року є одним з основних документів, що регулюють сферу поводження з ядерними та радіоактивними речовинами, юрисдикція якої поширюється на держави, які $\epsilon$ їі учасниками. Разом із тим необхідно брати до уваги і специфіку правового регулювання суспільних відносин такого типу в конкретній державі або групі держав.

Іншим аспектом проблеми поводження з радіоактивними речовинами та ядерними матеріалами на міжнародному рівні $€$ їх транспортування. Під час транспортування радіоактивних речовин особливої уваги потребує визначення необхідних заходів щодо ліквідації наслідків можливих аварій. Для оперативної оцінки рівня радіаційної небезпеки, що виникає під час аварії, МАГАТЕ була розроблена і прийнята класифікація аварій за трьома ступенями небезпеки з визначенням в кожному випадку конкретних заходів щодо забезпечення безпеки, проведення рятувальних робіт тощо. Наприклад, для перевезень матеріалів, що діляться, потрібен супроводжуючий персонал, а для деяких
Протидія злочинності: проблеми практики та науково-методичне забезпечення

видів - охорона. У кожній країні $\epsilon$ правила фізичного захисту (захист від розкрадань) матеріалів, що діляться, під час транспортування.

Взагалі вищезазначене МАГАТЕ (Міжнародне агентство 3 атомної енергіï) має на меті найважливіший напрям діяльності, а саме забезпечення нерозповсюдження ядерної зброї. У 1968 році 102 країни підписали договір про нерозповсюдження ядерної зброї (ДНЯЗ). За Договором про нерозповсюдження ядерної зброї на МАГАТЕ покладена перевірка виконання зобов'язань його учасників. Контрольні функції Агентства, так звані гарантії МАГАТЕ, мають на меті не допустити в країнах, що не володіють ядерною зброєю, переключення ядерних матеріалів з мирного застосування на створення ядерної зброї. Перевірка може відбуватися тільки на основі угоди з державою, в якій має проводитися інспекція. Укладання угоди з МАГАТЕ про застосування гарантій $\epsilon$ обов'язковим для держав, що не володіють ядерною зброєю та приєднались до ДНЯЗ, і зумовлене статтею III ДНЯЗ. Повномасштабний контроль МАГАТЕ за всіма ядерними матеріалами в усій мирній ядерній діяльності поширюється на десятки країн світу, включаючи держави з розвиненою ядерною промисловістю. У добровільному порядку під гарантії Агентства поставили також окремі ядерні установки США, Велика Британія, Франція, Китай, Росія. Досі діє 225 угод про гарантії з 141 державою [3, с. 1].

Висновки. Аналіз проблемних питань щодо запобігання суспільно небезпечних дій (бездіяльності), які пов'язані з обігом ядерних матеріалів і радіоактивних речовин, наголошує про необхідність запобігання незаконному поводженню з радіоактивними речовинами та ядерними матеріалами, що призведе до збереження навколишнього середовища не лише нашої країни, а і світу загалом.

\section{Література}

1. Концепция обращения с РАО Украины. Киев, 1993. 485 C.

2. Маслюк О.В. Розслідування злочинів у сфері обліку радіоактивних матеріалів : автореф. ... дис. канд. юрид. наук. Київ, 2008. 16 с.

3. Міжнародне_агентство_3_атомної_енергії. URL: https://uk.wikipedia.org/wiki/.

Долішук М. Т., слухач магістратури факультету № 3 Одеського державного університету внутрішніх справ

Плужнік О. І., кандидат юридичних наук, доцент, професор кафедри кримінального права та кримінології Одеського державного університету внутрішніх справ 